Article received 04.09.2019 p.

Article accepted 31.10.2019 p.

$@ \bowtie$ Correspondence author УдК 657.47.011.1

A. Z. Didyk

andriydz1001@gmail.com

А. З. Дідик

Львівський національний університет ім. Івана Франка, м. Львів, Украӥна

\title{
ОБЛІК ВИРОБНИЧИХ ВИТРАТ НА ХЛІБОПЕКАРСЬКИХ ПІДПРИЄМСТВАХ УКРАЇНИ
}

З'ясовано зміст поняття витрати. Розглянуто особливості нормативного методу обліку витрат на хлібопекарських підприємствах, визначено його основні завдання. Встановлено, які складові входять до витрат на виробництво хлібопекарської продукції. Досліджено особливості обліку виробничих витрат на хлібопекарських підприємствах України. Визначено проблеми обліку змінних і постійних загальновиробничих витрат та запропоновано шлях їх вирішення. Запропоновано вдосконалити нормативну базу шляхом покращення класифікації загальновиробничих витрат, деталізувати план рахунків бухгалтерського обліку з конкретизацією статей загальновиробничих витрат. Обгрунтовано значення рецептур у розрахунку собівартості виготовленої продукції. Встановлено основні технологічні особливості виробництва хлібобулочних виробів та розглянуто їх вплив на облік виробничих витрат. Розглянуто особливості технологічних витрат під час виготовлення хлібобулочних виробів, технологічних витрат на складах і комунікаціях. З'ясовано, що нормування витрат виходу хліба використовують для встановлення порядку у витраті основної сировини хлібопекарського виробництва. Наведено основні показники, які використовують у розрахунку норми виходу хліба. Обгрунтовано закономірності розрахунку планової витрати борошна. Виокремлено найпоширеніші бухгалтерські проведення, пов'язані з виробництвом продукції на хлібопекарських підприємствах.

Ключові слова: нормативний метод; загальновиробничі витрати; технологічні витрати; калькуляція; норма виходу хліба; вологість борошна.

Вступ. Система обліку виробничих витрат має стратегічне значення для хлібопекарських підприємств України. Підвищена увага до обліку виробничих витрат пов'язана з потребою врахування змін бізнес-середовища, що змушує хлібопекарські підприємства знаходити нові підходи до вдосконалення цього процесу, опрацьовувати нові форми обліку виробничих витрат. Облік виробничих витрат повинен забезпечити отримання достовірних даних про досягнутий його рівень, які потрібні для управління, контролю за дотриманням норм виробничого споживання засобів і предметів праці та живої праці для обчислення собівартості продукції та оцінення діяльності підприємства. Методика обліку виробничих витрат $є$ невід'ємним складником системи бухгалтерського обліку хлібопекарського підприємства. Ї̈̈ важливість супроводжується потребою адаптації теорії та практики вітчизняного бухгалтерського обліку відповідно до вимог міжнародних стандартів. Усі зазначені обставини доводять актуальність розкриття особливостей обліку виробничих витрат на хлібопекарських підприємствах України.

Аналіз останніх досліджень і публікацій. Облік виробничих витрат - істотний чинник підвищення ефективності господарської діяльності як на рівні окремих хлібопекарських підприємств, так і в масштабах усієї країни. Це питання досліджено у працях багатьох вітчизняних учених-економістів, таких як: Р. В. Самольотов, С. І. Саченко, І. В. Христофорова, О. Д. Гор- бач, В. М. Калашніков, Н. В. Клєцова, С. І. Савченко та ін. Проте така проблематика потребує подальшого висвітлення.

Викладення основного матеріалу. В умовах ринкової економіки успішна робота кожного промислового підприємства, і хлібопекарських підприємств зокрема, багато в чому залежить від вірно обраної системи обліку виробничих витрат. Від того, наскільки точно та своєчасно вони відображаються в бухгалтерському обліку, залежить точність і достовірність фінансового результату, який визначає підприємство.

В Україні $є$ низка нормативних актів, що регулюють облік витрат на хлібопекарських підприємствах. Методологічні та методичні засади формування інформації про витрати в бухгалтерському обліку визначає П(С)БО 16 "Витрати". Відповідно до П(С)БО 16, "витратами звітного періоду визнаються або зменшення активів, або збільшення зобов'язань, що призводить до зменшення власного капіталу підприємства (за винятком зменшення капіталу внаслідок його вилучення або розподілу власниками), за умови, що ці витрати можуть бути достовірно оцінені" (Polozhennia, 1999).

За сучасних умов господарювання для хлібопекарських підприємств важливим залишається питання вибору оцінки матеріальних ресурсів при їх відпуску у виробництво. Одним з найоптимальніших можна вважати метод обліку витрат на виробництво по підрозділах 3 елементами нормативного. Нормативний метод - це ос-

Інформація про авторів:

Дідик Андрій Зіновійович, аспірант, кафедра обліку і аудиту. Email: andriydz@gmail.com

Цитування за ДстУ: Дідик А. З. Облік виробничих витрат на хлібопекарських підприємствах України. Науковий вісник НлтУ України. 2019, т. 29, № 8. С. 93-96.

Citation APA: Didyk, A. Z. (2019). Accounting for production costs at the bakery enterprises of Ukraine. Scientific Bulletin of UNFU, 29(8), 93-96. https://doi.org/10.36930/40290816 
новний метод виробничого обліку, він спрямований на впровадження прогресивних норм витрат, дійовий контроль за рівнем витрат виробництва, що сприяє використанню даних обліку для виявлення резервів зниження собівартості продукції. Система калькулювання нормативних витрат включає:

- установлення нормативів витрат;

- нагромадження даних про фактичні витрати;

- аналіз відхилень і складання звітності;

- дослідження причин відхилень;

- зміни нормативних витрат (установлення нових стандартів), якщо у цьому є потреба (Korolova, 2015).

До основних завдань нормативного методу відносять оперативний аналіз виробничих витрат і запобігання нераціональному використанню ресурсів.

Витрати на виробництво хлібопекарської продукції включають:

- сировину і матеріали;

- паливо й електроенергію на технологічні цілі;

- заробітну плату і відрахування з неї на соціальні заходи;

- витрати на використання й утримання устаткування;

- адміністративні витрати;

- загальновиробничі витрати;

- витрати на збут.

Однак, відповідно до досліджень О. Д. Горбач, основну частку у собівартості хліба займають борошно, інші основні матеріали, транспортно-заготівельні витрати, паливо й електроенергія на технологічні цілі, основна і додаткова заробітна плата, загальновиробничі витрати (Horbach, 2013).

У сучасних умовах для хлібопекарських підприємств надзвичайно важливим є правильний вибір методу обліку загальновиробничих витрат і бази їх розподілу, адже від цього залежить повнота включення загальновиробничих витрат до собівартості продукції i, відповідно, зменшення або зростання чистого прибутку, що $\epsilon$ джерелом подальшого функціонування підприємства. Також, згідно з П(С)БО № 16, "загальновиробничі витрати розподіляються на постійні та змінні. Перелік і склад змінних і постійних загальновиробничих витрат встановлюються підприємством і зазначаються в наказі про облікову політику, тому що в сучасній нормативній базі немає чіткого переліку змінних і постійних загальновиробничих витрат, та й самі витрати неможливо однозначно віднести до постійних або змінних, тому що існує ще такий вид витрат, як змішані витрати, які містять в собі змінну і постійну частини" (Shmyhol, Rybalko \& Yeremenko, 2015). Вони значно ускладнюють процес обліку витрат. Вирішенням проблеми обліку таких витрат можна відзначити більш глибоке дослідження природи їх виникнення. Для управління змішаними витратами потрібно визначити вплив чинників витрат на їхню величину і наявність зв'язку між ними у певний період часу. Також потрібно вдосконалити нормативне забезпечення шляхом покращення класифікації загальновиробничих витрат, що розкриватимуть цільове призначення й економічний зміст витрат, враховуватимуть організаційну структуру та особливості підприємства. Потрібно ввести субрахунки у план рахунків бухгалтерського обліку для конкретизації статей загальновиробничих витрат.

До постійних витрат хлібопекарського підприємства можна віднести витрати на електроенергію і пальне на технологічні цілі, які не залежать від обсягу продукції, адже час і температура випікання не змінюються в разі зміни обсягу завантаження печі.

Сировина, основні матеріали і напівфабрикати, що належать до змінних витрат, відпускаються на виробництво за встановленими на підприємстві рецептурами. У них враховується економія сировини, матеріалів і напівфабрикатів на одиницю хлібобулочної продукції. Норми в рецептурах повинні бути нижчими за чинні та прогресивними. За ними визначається собівартість під час складання калькуляції на окремі види продукції і за ними ж визначаються відхилення від установлених норм. На думку К. В. Чичуліної, калькуляція - це "заключний етап обліку витрат на виробництво і виходу продукції, у процесі якого визначеними прийомами i методами групуються витрати й обчислюється собівартість продукції" (Chychulina, Mishchuk \& Arzumanian, 2017).

Також важливе значення має норма виходу хліба мінімально допустимий обсяг хліба, виготовленого зі 100 кг борошна та іншої сировини відповідно до утвердженої рецептури. Нормування витрат виходу хліба направлено на встановлення порядку у витраті основної сировини хлібопекарського виробництва для іiі раціонального використання і забезпечення випуску продукції, що відповідає чинним показникам якості. Вихід хліба визначається відношенням кількості виготовленого хліба до кількості фактично витраченого борошна. На кожному хлібопекарському підприємстві встановлюють свою орієнтовану мінімальну норму виходу хліба. Вона визначається на основі технології приготування тіста, застосовуваного обладнання, хлібопекарських властивостей борошна, що переробляється. Норми виходів хлібобулочних виробів встановлюють за базової вологості борошна 14,5 \% для кожного виробу залежно від сорту борошна, випічки, способу реалізації (ваговий, штучний) тощо. Якщо змінюється вологість борошна, то змінюється і норма виходу: чим нижча вологість, тим вища норма виходу і навпаки (Kuziv, Mykhailyshyn, Hudz \& Berestetska, 2013). Для розрахунку виходу хліба використовують такі показники:

- чисті витрати борошна та додаткової сировини на виробництво продукції;

- технологічні витрати для виготовлення хлібобулочних виробів, а також на складах і комунікаціях.

Технологічні витрати для виготовлення хлібобулочних виробів - це борошно, напівфабрикати хлібопекарського виробництва і готові вироби, використання яких зумовлено технологічним процесом виробництва хлібобулочних виробів і їх збереженням. Технологічні витрати для виробництва хлібобулочних виробів потрібно знижувати до оптимальної величини.

До технологічних витрат для виготовлення хлібобулочних виробів можна віднести:

- затрати сухих речовин для бродіння тіста;

- затрати борошна на формування тістових заготовок;

- упік хлібобулочних виробів (зменшення маси тіста при випіканні);

- зменшення маси хлібобулочних виробів під час транспортування від печі та укладання у вагонетки;

- усушка хлібобулочних виробів (зменшення маси під час зберігання).

Технологічні витрати на складах і комунікаціях - це борошно, напівфабрикати та готова продукція, втрачена 
під час зберігання, транспортування, а також через недосконалість або дефекти устаткування. Ці витрати потрібно, за можливості, повністю ліквідовувати шляхом дотримання правил експлуатації устаткування i постійного контролю за його станом, чіткого виконання технологічних режимів виробництва. Технологічні витрати на складах і комунікаціях включають:

- витрати борошна на першій стадії процесу виготовлення продукції (прийом борошна і замішування тіста);

- витрати тіста і борошна під час посадки сформованих тістових заготовок у піч;

- витрати у вигляді крихти під час виймання хлібобулочних виробів з печі, під час транспортування та укладання на вагонетки;

- витрати від неточності маси хлібобулочних виробів;

- витрати від перероблення браку.

Значення планового виходу хлібобулочних виробів завжди є нижчим за граничне, що може бути досягнуте за оптимальних умов виробництва. Це дає змогу підприємствам за рахунок внутрішніх резервів перевиконати норму виходу хліба. Для економії $1 \%$ борошна норму виходу потрібно перевиконати на $1,5 \%$.

Фактичний вихід хлібобулочних виробів, як i пов'язані з ним економію чи перевитрату борошна, розраховують залежно від потреб підприємства, для кожної зміни, доби, місяця або року роботи. Інформацію про витрату сировини і матеріалів, кількість виготовле- ної продукції отримують 3 виробничих звітів, а інформацію про вологість використаного борошна - 3 якісних посвідчень. Фактичний вихід хлібобулочних виробів розраховують як відношення маси виготовленого хліба до маси використаного борошна. Масу хлібобулочних виробів розраховують множенням стандартної маси виробів на їхню кількість. Проте від отриманого результату потрібно відняти масу виробів, перероблених вдруге (у вигляді хлібної і сухарної крихти).

Для розрахунку економії чи перевитрат борошна підраховують планову витрату борошна, яка досягається в разі точного дотримання норми виходу хлібобулочних виробів, і порівнюється 3 фактичною витратою. Для цього потрібно підрахувати масу виготовленої продукції, масу витраченого борошна і плановий вихід, скорегований на вологість борошна.

На більшості хлібопекарських підприємств України кореспонденція рахунків формується у програмному продукті 1C Підприємство. Для рахунку 23 "Виробництво" регістр синтетичного обліку можливо роздрукувати як оборотно-сальдову відомість, обороти по рахунку, аналіз рахунку або картку рахунку залежно від потреб користувача. Найпоширеніші бухгалтерські проведення, пов'язані з виробничими процесами на хлібопекарських підприємствах, наведено в таблиці.

Таблиця. Бухгалтерські проведення, пов'язані з виробничими процесами на хлібопекарських підприсмствах

\begin{tabular}{|l|c|c|}
\hline \multicolumn{1}{|c|}{ Зміст операції } & \multicolumn{2}{c|}{ Кореспонденція рахунків } \\
\cline { 2 - 4 } & \multicolumn{2}{c|}{ Дт } \\
\hline Надійшла сировина від постачальника (борошно, дріжджі, сіль, солод тощо) & 201 & 631 \\
\hline Нараховано витрати на транспортування сировини & 201 & 631 \\
\hline Списано собівартість сировини на виготовлення продукції & 23 & 201 \\
\hline Нараховано заробітну плату працівникам, зайнятим виробництвом продукції & 23 & 661 \\
\hline $\begin{array}{l}\text { Нараховано єдиний соціальний внесок на заробітну плату працівників, зайнятих виробниц- } \\
\text { твом продукції }\end{array}$ & 23 & 65 \\
\hline Нараховано амортизацію обладнання, що використовується для виробництва продукції & 23 & 13 \\
\hline Переміщено виготовлену продукцію з цеху на склад & 26 & 23 \\
\hline
\end{tabular}

Висновки. Отже, витрати - це зменшення активів або збільшення зобов'язань, що призводить до зменшення власного капіталу підприємства. Найоптимальнішим для хлібопекарських підприємств є нормативний метод обліку витрат, що спрямований на впровадження прогресивних норм витрат і дієвий контроль за рівнем витрат виробництва. До його основних завдань належать оперативний аналіз витрат виробництва та запобігання нецільовому використанню ресурсів.

Основну частку у собівартості хлібопекарської продукції займають сировина, основні матеріали і напівфабрикати, що відпускаються на виробництво за встановленими на підприємстві рецептурами. У них враховується економія сировини, матеріалів і напівфабрикатів на одиницю хлібобулочної продукції. Також важливе значення має норма виходу хлібобулочних виробів мінімально допустима кількість продукції, отриманої зі 100 кг борошна та іншої сировини, внесеного відповідно до затвердженої рецептури. Для розрахунку виходу хлібобулочних виробів враховуються чиста витрата борошна й іншої сировини, технологічні витрати при виробленні хлібобулочних виробів, на складах і комунікаціях. Плановий вихід хлібобулочних виробів встановлюють нижче граничного значення, завдяки чому кожне підприємство може перевиконати норму виходу, використовуючи внутрішні резерви.
Перспективою подальших досліджень є аналіз процесу управління виробничими витратами в системі обліку хлібопекарських підприємств і недопущення перевитрат виробничих ресурсів.

\section{Перелік використаних джерел}

Chychulina, K. V., Mishchuk, Ye. M., \& Arzumanian, A. S. (2017). Modern cost accounting methods. Economy and society, 13, 14351442. [In Ukrainian].

Horbach, O. D. (2013). The cost of a simple bread recipes and features its planning in the bread and bakery industry. Ekonomic Forum, 4, 4-8. [In Ukrainian].

Korolova, O. I. (2015). Problems and development prospects of production costs accounting. Ekonomika ta upravlinnia na transporti, 1, 79-90. [In Ukrainian].

Kuziv, M. S., Mykhailyshyn, N. P., Hudz, N. V., \& Berestetska, O. M. (2013). Accounting in the branches of industry. Ternopil: KROK. [In Ukrainian].

Polozhennia. (1999). Polozhennia (standart) bukhhalterskoho obliku 16 "Vytraty", zatverdzhene nakazom Ministerstva finansiv Ukrainy vid 31 hrudnia 1999 r. № 318 (zi zminamy i dopovnenniamy). Retrieved from: https://zakon.rada.gov.ua/go/z0027-00. [In Ukrainian].

Shmyhol, N. M., Rybalko, O. M., \& Yeremenko, P. V. (2015). Actual problems and improvement of cost accounting in the enterprises. Bulletin of Zaporizhzhya National University, 3(27), 108-114. [In Ukrainian]. 


\section{ACCOUNTING FOR PRODUCTION COSTS AT THE BAKERY ENTERPRISES OF UKRAINE}

Current economic transformations at the bakery enterprises require the solution of many technical, industrial and organizational problems. Consequently, there is a need to develop new approaches to the organization and methodology of accounting for production cost of bakery enterprises and to determine the financial result of enterprises. The following methods were used to conduct the research: synthesis - for generalization of various aspects of accounting; specification - to substantiate the contents of the forms of accounting; statistical and analytical calculations, comparisons - for the comparison of data in dynamics; grouping - to determine the dependence of indicators on each other. The article examines the legislative and regulatory aspects of accounting for costs at bakery enterprises. The study considered the disadvantages of cost accounting, current expenses of enterprises, costs associated with the production of bakery products and the articles of costing. The article determined content of the concept of expense and considered normative method peculiarities of accounting of expenses at bakery enterprises. Main tasks of this method include operational analysis of production costs and the prevention of inappropriate use of resources. The article also established which components are included in the cost of bakery products production and conducted the study of the characteristics of accounting for production costs at bakery enterprises of Ukraine. The authors determined the problems of accounting of variables and constant total production costs and proposed the way of their solution. Moreover, they substantiated the value of recipes in calculating the cost price of manufactured products and determined that the main share in the cost of bread is occupied by flour, other main materials, transport and procurement costs, fuel for technological purposes, electricity for technological purposes, basic and additional wages. The article also established basic technological features of bakery products production and considered their influence on accounting of production costs. The authors have given the main indicators used to calculate the norm of bread output. Consequently, considering the fact that the value of production costs directly affects profitability, the issue of ensuring the optimal level of costs is put forward. It is impossible to achieve this without a well-adjusted cost accounting system.

Keywords: normative method; total expenditures; technological costs; calculation; the norm of bread output; humidity of flour. 